Article

\title{
Biological Activities of the Essential Oil from Erigeron floribundus
}

\author{
Riccardo Petrelli ${ }^{1, *}$, Giuseppe Orsomando ${ }^{2}$, Leonardo Sorci ${ }^{2}$, Filippo Maggi ${ }^{1, *}$, \\ Farahnaz Ranjbarian ${ }^{3}$, Prosper C. Biapa Nya ${ }^{4}$, Dezemona Petrelli ${ }^{5}$, Luca A. Vitali ${ }^{1}$, \\ Giulio Lupidi ${ }^{1}$, Luana Quassinti ${ }^{1}$, Massimo Bramucci ${ }^{1}$, Anders Hofer ${ }^{3}$ and \\ Loredana Cappellacci $^{1}$
}

1 School of Pharmacy, University of Camerino, Camerino 62032, Italy; luca.vitali@unicam.it (L.A.V.); giulio.lupidi@unicam.it (G.L.); luana.quassinti@unicam.it (L.Q.); massimo.bramucci@unicam.it (M.B.); loredana.cappellacci@unicam.it (L.C.)

2 Department of Clinical Sciences, Section of Biochemistry, Polytechnic University of Marche, Ancona 60131, Italy; orsomando@univpm.it (G.O.); 1.sorci@univpm.it (L.S.)

3 Department of Medical Biochemistry and Biophysics, Umeå University, Umeå 90187, Sweden; farahnaz.ranjbarian@umu.se (F.R.); anders.hofer@umu.se (A.H.)

4 Laboratory of Medicinal Plant Biochemistry, Food Science and Nutrition, Department of Biochemistry, Faculty of Sciences, University of Dschang, PO Box 67, Dschang, Cameroon; prbiapa@yahoo.fr

5 School of Biosciences and Veterinary Medicine, University of Camerino, Camerino 62032, Italy; dezemona.petrelli@unicam.it

* Correspondence: riccardo.petrelli@unicam.it (R.P.); filippo.maggi@unicam.it (F.M.); Tel.: +39-0737-402239 (R.P.); +39-0737-404506 (F.M.); Fax: +39-0737-637345 (R.P. \& F.M.)

Academic Editor: Derek J. McPhee

Received: 12 July 2016; Accepted: 11 August 2016; Published: 13 August 2016

\begin{abstract}
Erigeron floribundus (Asteraceae) is an herbaceous plant widely used in Cameroonian traditional medicine to treat various diseases of microbial and non-microbial origin. In the present study, we evaluated the in vitro biological activities displayed by the essential oil obtained from the aerial parts of E. floribundus, namely the antioxidant, antimicrobial and antiproliferative activities. Moreover, we investigated the inhibitory effects of $E$. floribundus essential oil on nicotinate mononucleotide adenylyltransferase (NadD), a promising new target for developing novel antibiotics, and Trypanosoma brucei, the protozoan parasite responsible for Human African trypanosomiasis. The essential oil composition was dominated by spathulenol $(12.2 \%)$, caryophyllene oxide $(12.4 \%)$ and limonene $(8.8 \%)$. The E. floribundus oil showed a good activity against Staphylococcus aureus (inhibition zone diameter, IZD of $14 \mathrm{~mm}$, minimum inhibitory concentration, MIC of $512 \mu \mathrm{g} / \mathrm{mL}$ ). Interestingly, it inhibited the NadD enzyme from S. aureus $\left(\mathrm{IC}_{50}\right.$ of $98 \mu \mathrm{g} / \mathrm{mL}$ ), with no effects on mammalian orthologue enzymes. In addition, $T$. brucei proliferation was inhibited with $\mathrm{IC}_{50}$ values of $33.5 \mu \mathrm{g} / \mathrm{mL}$ with the essential oil and $5.6 \mu \mathrm{g} / \mathrm{mL}$ with the active component limonene. The essential oil exhibited strong cytotoxicity on HCT 116 colon carcinoma cells with an $\mathrm{IC}_{50}$ value of $14.89 \mu \mathrm{g} / \mathrm{mL}$, and remarkable ferric reducing antioxidant power (tocopherol-equivalent antioxidant capacity, TEAC $=411.9 \mu \mathrm{mol} \cdot \mathrm{TE} / \mathrm{g}$ ).
\end{abstract}

Keywords: Erigeron floribundus; essential oil; antimicrobial; NadD; Trypanosoma brucei; cytotoxicity; antioxidant; limonene; caryophyllene oxide

\section{Introduction}

Erigeron floribundus (Kunth) Sch. Bip. (Asteraceae) is an herbaceous plant, $1.5 \mathrm{~m}$ in height, with pubescent, lanceolate leaves and flowers in yellowish panicles. In Cameroon, it is commonly found as a weed along roadsides, and it is widely used in folk medicine to treat angina, female 
infertility, AIDS, dental pain, headache and various diseases of microbial and non-microbial origin [1-6]. The leaf aqueous extract was proven to possess analgesic, anti-inflammatory and immunomodulatory activity [1,2], the dichloromethane extract inhibition against dermatophytes [7], and the leaf ethanolic and pentane extract antiplasmodial activity [8]. Despite the interest in its bioactivity, the plant has received little phytochemical investigation. With regard to the essential oil, a previous work performed on Cameroonian plants showed sesquiterpene hydrocarbons as the major essential oil constituents [9].

Given the wide use of the plant in traditional medicine, we evaluated the in vitro biological activities displayed by the essential oil obtained from the aerial parts of E. floribundus, namely the antioxidant, antiproliferative and antimicrobial activities that were investigated by 2,2-diphenyl-1-picrylhydrazyl (DPPH), 2,2'-azino-bis(3-ethylbenzothiazoline-6-sulphonic acid (ABTS), ferric reducing antioxidant power (FRAP), 3-(4,5-dimethyl-2-thiazolyl)-2,5-diphenyl-2H-tetrazoliumbromide (MTT), and agar disc diffusion and microdilution methods, respectively.

Because essential oils represent an interesting alternative approach against the occurrence of drug resistance in many infectious bacterial pathogens [10] and fighting protozoan parasites [11], we completed the work by investigating the activity of E. floribundus essential oil on nicotinate mononucleotide adenylyltransferase (NadD) and Trypanosoma brucei. Being natural in origin, essential oils and their components are believed to be environmentally favourable and user-friendly [12]. Moreover, using innovative technologies, such as nanoencapsulation, many limits of their application in medicine (mainly low water solubility and stability, high volatility and side effects) could be overcome [13].

NadD occupies a central position in bacterial $\mathrm{NAD}^{+}$biosynthesis and is required for both de novo and salvage routes to generate $\mathrm{NAD}^{+}[14-16]$. NadD has been recognized as a promising new target for developing novel antibiotics due to its crucial role in synthesizing $\mathrm{NAD}^{+}$[17-20]. Another attractive aspect of targeting NadD is that it is highly conserved in the overwhelming majority of bacterial species including most pathogens. Therefore, drugs developed based on the inhibition of NadD have the potential of possessing wide-spectrum antibacterial activity.

T. brucei is a protozoan parasite responsible for Human African trypanosomiasis (HAT), a neglected disease also known as African sleeping sickness. HAT threatens primarily rural populations and is fatal unless treated. To date, there are a few drugs approved, although none of them are satisfactory, due to treatment failures and toxicity, and the parenteral administration that is inappropriate in settings with poor medical infrastructure. Therefore, there is an urgent need to improve HAT treatment by enhancing the oral administration and the discovery and development of cost-effective new drugs. Drug discovery efforts are nowadays directed towards natural products and medicinal plants represent a validated source for discovery of new lead compounds and standardized herbal medicines against trypanosomiasis [21].

\section{Results}

\subsection{Essential Oil Analysis}

The composition of the essential oil hydrodistilled from the aerial parts of E. floribundus is reported in Table 1. GC-MS analysis revealed that the essential oil had a complex chemical profile. Separation of volatile components was accomplished by using both polar and apolar columns (HP-5 MS and DB-WAX, respectively). A total of eighty-five constituents were identified accounting for $78.6 \%$ of the total composition. The main fraction of the essential oil was given by sesquiterpenes $(60.4 \%)$, which were represented by oxygenated compounds (38.5\%) and hydrocarbons $(21.9 \%)$. Main representatives of these groups were caryophyllene oxide $(12.4 \%)$ and spathulenol $(12.2 \%)$, and $(E)-\beta$-farnesene (5.5\%) and $(E)$-caryophyllene $(4.2 \%)$, respectively. Monoterpenes constituted a minor part of the oil $(13.0 \%)$, with hydrocarbons $(11.5 \%)$ as the predominant components. Among them, limonene was the most representative $(8.8 \%)$. 
Table 1. Composition of the essential oil hydrodistilled from the aerial parts of Erigeron floribundus.

\begin{tabular}{|c|c|c|c|c|c|c|c|}
\hline \multirow{2}{*}{ N. } & \multirow{2}{*}{ Component ${ }^{1}$} & \multicolumn{2}{|c|}{ RI Calc. $^{2}$} & \multicolumn{2}{|c|}{ RI Lit. ${ }^{3}$} & \multirow{2}{*}{$\%^{4}$} & \multirow{2}{*}{ ID $^{5}$} \\
\hline & & HP-5MS & DBWAX & Apolar & Polar & & \\
\hline 1 & butyl methyl ketone & 780 & 1088 & 786 & 1088 & $\operatorname{tr}^{6}$ & RI, MS \\
\hline 2 & hexanal & 792 & 1024 & 801 & 1024 & 0.1 & RI, MS \\
\hline 3 & (3E)-hexenol & 844 & 1371 & 844 & 1371 & 0.2 & RI, MS \\
\hline 4 & $n$-hexanol & 858 & 1363 & 863 & 1363 & 0.1 & RI, MS \\
\hline 5 & 1-(2-methyl-2-cyclopenten-1-yl)-ethanone & 871 & & & & $\operatorname{tr}$ & MS \\
\hline 6 & $\alpha$-pinene & 921 & 1026 & 932 & 1026 & 0.2 & Std \\
\hline 7 & sabinene & 960 & 1125 & 969 & 1125 & $\operatorname{tr}$ & RI, MS \\
\hline 8 & $\beta$-pinene & 962 & 1112 & 974 & 1112 & 2.1 & Std \\
\hline 9 & myrcene & 983 & 1167 & 988 & 1165 & 0.1 & Std \\
\hline 10 & 2-pentyl furan & 983 & 1231 & 984 & 1231 & 0.1 & RI, MS \\
\hline 11 & p-cymene & 1017 & 1271 & 1020 & 1272 & $\operatorname{tr}$ & Std \\
\hline 12 & limonene & 1020 & 1199 & 1024 & 1199 & 8.8 & Std \\
\hline 13 & $(E)$ - $\beta$-ocimene & 1042 & 1255 & 1044 & 1255 & 0.1 & RI, MS \\
\hline 14 & $\gamma$-terpinene & 1051 & 1253 & 1054 & 1255 & $\operatorname{tr}$ & Std \\
\hline 15 & terpinolene & 1080 & 1283 & 1086 & 1282 & $\operatorname{tr}$ & RI, MS \\
\hline 16 & linalool & 1096 & 1555 & 1095 & 1556 & 0.1 & Std \\
\hline 17 & $n$-nonanal & 1102 & 1393 & 1100 & 1395 & $\operatorname{tr}$ & RI, MS \\
\hline 18 & (E)-4,8-dimethyl-1,3,7-nonatriene & 1112 & & & & $\operatorname{tr}$ & MS \\
\hline 19 & trans- $p$-mentha-2,8-dien-1-ol & 1114 & & 1119 & & $\operatorname{tr}$ & RI, MS \\
\hline 20 & trans-pinocarveol & 1129 & 1656 & 1135 & 1657 & 0.1 & Std \\
\hline 21 & nerol oxide & 1150 & & 1154 & & $\operatorname{tr}$ & RI, MS \\
\hline 22 & pinocarvone & 1153 & 1563 & 1160 & 1565 & 0.1 & RI, MS \\
\hline 23 & lavandulol & 1163 & 1686 & 1170 & 1686 & 0.1 & RI, MS \\
\hline 24 & terpinen-4-ol & 1169 & 1600 & 1174 & 1600 & 0.1 & Std \\
\hline 25 & trans-isocarveol & 1180 & 1838 & 1175 & & $\operatorname{tr}$ & RI, MS \\
\hline 26 & $\alpha$-terpineol & 1182 & 1688 & 1186 & 1690 & 0.2 & Std \\
\hline 27 & myrtenal & 1188 & 1648 & 1195 & 1648 & 0.1 & RI, MS \\
\hline 28 & myrtenol & 1188 & 1794 & 1194 & 1794 & 0.1 & Std \\
\hline 29 & $\beta$-cyclocitral & 1212 & & 1217 & & 0.1 & RI, MS \\
\hline 30 & nerol & 1223 & 1840 & 1227 & 1838 & 0.4 & Std \\
\hline 31 & carvone & 1236 & 1744 & 1239 & 1745 & 0.1 & Std \\
\hline 32 & geraniol & 1253 & 1850 & 1249 & 1852 & $\operatorname{tr}$ & Std \\
\hline 33 & perilla aldehyde & 1265 & 1783 & 1265 & 1784 & $\operatorname{tr}$ & RI, MS \\
\hline 34 & geranial & 1268 & 1730 & 1264 & 1730 & $\operatorname{tr}$ & Std \\
\hline 35 & perilla alcohol & 1291 & 2028 & 1290 & 2029 & 0.1 & RI, MS \\
\hline 36 & silphiperfol-5-ene & 1310 & 1421 & 1326 & & 0.3 & RI, MS \\
\hline 37 & $\alpha$-cubebene & 1338 & 1457 & 1345 & & 0.1 & RI, MS \\
\hline 38 & eugenol & 1351 & 2164 & 1356 & 2167 & 0.1 & Std \\
\hline 39 & $\alpha$-copaene & 1362 & 1488 & 1374 & 1488 & 0.7 & RI, MS \\
\hline 40 & modheph-2-ene & 1363 & 1516 & 1377 & & 0.7 & RI, MS \\
\hline 41 & $\alpha$-isocomene & 1370 & 1529 & 1377 & & 0.5 & RI, MS \\
\hline 42 & $\beta$-cubebene & 1378 & & 1379 & & 0.2 & RI, MS \\
\hline 43 & $\beta$-elemene & 1380 & & 1389 & & 0.2 & RI, MS \\
\hline 44 & $\beta$-isocomene & 1387 & & 1407 & & 0.4 & RI, MS \\
\hline 45 & (Z)-caryophyllene & 1392 & 1570 & 1408 & & 2.3 & RI, MS \\
\hline 46 & (E)-caryophyllene & 1403 & 1590 & 1417 & 1585 & 4.2 & Std \\
\hline 47 & $\beta$-copaene & 1414 & 1535 & 1430 & & 0.4 & RI, MS \\
\hline 48 & $\beta$-gurjunene & 1422 & & 1431 & & 0.1 & RI, MS \\
\hline 49 & $\alpha$-trans-bergamotene & 1425 & 1583 & 1432 & 1586 & 2.1 & RI, MS \\
\hline 50 & $\alpha$-humulene & 1437 & 1663 & 1452 & 1665 & 1.0 & Std \\
\hline 51 & geranyl acetone & 1447 & & 1453 & & 0.1 & RI, MS \\
\hline 52 & (E)- $\beta$-farnesene & 1451 & 1745 & 1454 & 1745 & 5.5 & Std \\
\hline 53 & $\gamma$-muurolene & 1464 & 1683 & 1478 & & 0.4 & RI, MS \\
\hline 54 & germacrene D & 1466 & 1701 & 1484 & 1700 & 0.1 & RI, MS \\
\hline 55 & $\beta$-selinene & 1470 & & 1489 & & 0.1 & RI, MS \\
\hline 56 & ar-curcumene & 1473 & 1770 & 1479 & 1769 & $\begin{array}{l}0.1 \\
1.0\end{array}$ & RI, MS \\
\hline 57 & $(E)-\beta$-ionone & 1476 & 1934 & 1487 & 1936 & 0.1 & Std \\
\hline
\end{tabular}


Table 1. Cont.

\begin{tabular}{|c|c|c|c|c|c|c|c|}
\hline \multirow{2}{*}{ N. } & \multirow{2}{*}{ Component $^{1}$} & \multicolumn{2}{|c|}{ RI Calc. ${ }^{2}$} & \multicolumn{2}{|c|}{ RI Lit. ${ }^{3}$} & \multirow{2}{*}{$\% 4$} & \multirow{2}{*}{ ID $^{5}$} \\
\hline & & HP-5MS & DBWAX & Apolar & Polar & & \\
\hline 58 & cis- $\beta$-guaiene & 1481 & & 1492 & & 0.2 & RI, MS \\
\hline 59 & $\gamma$-curcumene & 1481 & 1673 & 1481 & & 0.2 & RI, MS \\
\hline 60 & $\alpha$-muurolene & 1487 & 1719 & 1500 & & 0.2 & RI, MS \\
\hline 61 & modhephen-8- $\beta$-ol & 1492 & & 1513 & & 0.2 & RI, MS \\
\hline 62 & $\gamma$-cadinene & 1499 & & 1513 & & 0.3 & RI, MS \\
\hline 63 & $\delta$-cadinene & 1511 & 1753 & 1522 & 1752 & 0.5 & RI, MS \\
\hline 64 & $\alpha$-calacorene & 1528 & 1907 & 1544 & & 0.1 & RI, MS \\
\hline 65 & (E)-nerolidol & 1557 & 2048 & 1561 & 2049 & 2.1 & Std \\
\hline 66 & spathulenol & 1564 & 2127 & 1577 & 2132 & 12.2 & RI, MS \\
\hline 67 & caryophyllene oxide & 1567 & 1977 & 1582 & 1983 & 12.4 & Std \\
\hline 68 & salvial-4(14)-en-1-one & 1577 & 2000 & 1594 & & 0.8 & RI, MS \\
\hline 69 & humulene epoxide II & 1591 & 2034 & 1608 & 2040 & 1.7 & RI, MS \\
\hline 70 & caryophylla-4(12),8(13)-dien-5 $\alpha$-ol & 1615 & & 1639 & & 0.6 & RI, MS \\
\hline 71 & caryophylla-4(12),8(13)-dien-5 $\beta$-ol & 1619 & & 1639 & & 1.0 & RI, MS \\
\hline 72 & tau-cadinol & 1626 & 2126 & 1625 & 2125 & 1.0 & RI, MS \\
\hline 73 & muurola-4,10(14)-dien-1-beta-ol & 1637 & & 1630 & & 1.0 & RI, MS \\
\hline 74 & $\alpha$-cadinol & 1640 & 2232 & 1652 & 2232 & 1.0 & RI, MS \\
\hline 75 & 14-hydroxy-9-epi-(E)-caryophyllene & 1656 & & 1668 & & 2.1 & RI, MS \\
\hline 76 & germacra-4(15),5,10(14)-trien-1- $\alpha$-ol & 1669 & & 1685 & & 2.1 & RI, MS \\
\hline 77 & pentadecanal & 1706 & 2041 & 1705 & 2041 & 0.6 & RI, MS \\
\hline 78 & $\beta$-bisabolenol & 1776 & & 1785 & & 0.2 & RI, MS \\
\hline 79 & 14-hydroxy- $\delta$-cadinene & 1787 & & 1788 & & 0.3 & RI, MS \\
\hline 80 & neophytadiene & 1831 & & & & 0.2 & MS \\
\hline 81 & 2-pentadecanone, 6,10,14-trimethyl- & 1837 & 2131 & 1838 & 2131 & 0.3 & RI, MS \\
\hline 82 & hexadecanoic acid & 1962 & 2918 & 1959 & 2917 & 2.5 & RI, MS \\
\hline 83 & (E)-phytol & 2094 & 2624 & 2096 & 2622 & 0.7 & Std \\
\hline 84 & $n$-pentacosane & 2500 & 2500 & 2500 & 2500 & $\operatorname{tr}$ & Std \\
\hline \multirow[t]{8}{*}{85} & $n$-heptacosane & 2700 & 2700 & 2700 & 2700 & $\operatorname{tr}$ & Std \\
\hline & Total identified (\%) & & & & & 78.6 & \\
\hline & Grouped compounds & & & & & & \\
\hline & Monoterpene hydrocarbons & & & & & 11.5 & \\
\hline & Oxygenated monoterpenes & & & & & 1.5 & \\
\hline & Sesquiterpene hydrocarbons & & & & & 21.9 & \\
\hline & Oxygenated sesquiterpenes & & & & & 38.5 & \\
\hline & Others & & & & & 5.2 & \\
\hline
\end{tabular}

${ }^{1}$ Compounds are listed in order of their elution from an HP-5MS column. Their nomenclature was in accordance with Adams [22]. ${ }^{2}$ Linear retention index on HP-5MS and DB-Wax column, experimentally determined using homologous series of C8-C30 alkanes. ${ }^{3}$ Linear retention index taken from Adams [22] and/or NIST08 [23] for apolar columns, and from FFNSC2 [24] and/or NIST08 for polar columns. ${ }^{4}$ Percentage values are means of three determinations with an RSD $\%$ for the main components below $5 \%$ in all cases. ${ }^{5}$ Identification methods: std, based on comparison with authentic compounds; MS based on comparison with Wiley. ADAMS and NIST08 MS database; RI, based on comparison of RI with those reported in ADAMS and NIST08. ${ }^{6}$ tr, traces (mean value below $0.1 \%$ ).

\subsection{Cytotoxicity Assessment}

General cell toxic effects of E. floribundus essential oil were evaluated using the MTT assay against the following human tumour cell lines: A375 human malignant melanoma cell line, MDA-MB 231 human breast adenocarcinoma cell line, and the HCT116 human colon carcinoma cell line. All cell lines were submitted to increasing concentrations of essential oil for $72 \mathrm{~h}$. The results, collected in Table 2, show that essential oil exhibited a significant growth inhibition against the examined human cancer cells and induced a concentration-dependent inhibitory effect in the dilutions ranging from $0.78-200 \mu \mathrm{g} / \mathrm{mL}$. The $\mathrm{IC}_{50}$ values of the essential oil were $14.9,20.8$, and $22.5 \mu \mathrm{g} / \mathrm{mL}$ on HCT116, MDA-MB 231, and A375 cell lines, respectively. 
Table 2. In vitro growth inhibition of tumor cells by Erigeron floribundus essential oil.

\begin{tabular}{|c|c|c|c|}
\hline & \multicolumn{3}{|c|}{ Cell Line $\left(\mathrm{IC}_{50} \mu \mathrm{g} / \mathrm{mL}\right)^{1}$} \\
\hline & A375 ${ }^{2}$ & MDA-MB $231^{3}$ & HCT116 $^{4}$ \\
\hline Essential oil & 22.5 & 20.8 & 14.9 \\
\hline $95 \%$ C.I. $^{5}$ & $20.6-24.6$ & $16.82-25.77$ & $13.10-17.00$ \\
\hline Positive control & & & \\
\hline Cisplatin & 0.5 & 2.5 & 2.5 \\
\hline $95 \%$ C.I. & $0.4-0.5$ & $2.0-3.0$ & $2.2-2.9$ \\
\hline
\end{tabular}

${ }^{1} \mathrm{IC}_{50}=$ the concentration of compound that affords a 50\% reduction in cell growth (after $72 \mathrm{~h}$ of incubation).

${ }^{2}$ Human malignant melanoma cell line. ${ }^{3}$ Human breast adenocarcinoma cell line. ${ }^{4}$ Human colon carcinoma cell line. ${ }^{5}$ C.I. Confidence interval.

\subsection{Antimicrobial Activity}

The essential oil of E. floribundus showed a good antimicrobial activity against Staphylococcus aureus using both disc diffusion and microdilution methods. The inhibition zone diameter (IZD) of almost $15 \mathrm{~mm}$ was indicative of a good activity. The corresponding minimum inhibitory concentration (MIC) was equal to $512 \mu \mathrm{g} / \mathrm{mL}$ (Table 3). S. aureus is Gram-positive as well as Enterococcus faecalis. The latter was also included in the panel of tested bacteria but resulted in being less susceptible to the essential oil than $S$. aureus (IZD $\cong 9 \mathrm{~mm}$ ) as confirmed by the much higher MIC value $(4096 \mu \mathrm{g} / \mathrm{mL}$ ). None of the Gram-negative bacterial species, namely E. coli and P. aeruginosa, were inhibited as assessed by the disc diffusion test. Therefore, antimicrobial susceptibility by the microdilution method was not investigated. In contrast, the yeast $C$. albicans growth was inhibited by the essential oil (IZD $=9 \mathrm{~mm}$ ), which showed a minimum inhibitory concentration of $512 \mu \mathrm{g} / \mathrm{mL}$ by the microdilution method.

Table 3. In vitro antimicrobial activity of Erigeron floribundus essential oil.

\begin{tabular}{|c|c|c|c|c|c|}
\hline \multirow{2}{*}{ Species } & \multirow{2}{*}{ Strain } & \multicolumn{2}{|c|}{ Essential Oil } & \multicolumn{2}{|c|}{ Reference Antibiotic $^{1}$} \\
\hline & & $\mathrm{IZD}^{2}(\mathrm{~mm})$ & $\operatorname{MIC}^{3}(\mu \mathrm{g} / \mathrm{mL})$ & IZD (mm) & $\operatorname{MIC}(\mu \mathrm{g} / \mathrm{mL})$ \\
\hline \multirow{5}{*}{ S. aureus } & ATCC 29213 & $14.3 \pm 0.6$ & 512 & $20.67 \pm 1.15$ & 0.25 \\
\hline & MRSA $^{4}-19$ & & 1024-2048 & & \\
\hline & MRSA-42 & & 512-1024 & & \\
\hline & MRSA-75 & & $512-1024$ & & \\
\hline & MRSA-101 & & 512-1024 & & \\
\hline E. faecalis & ATCC 29212 & $8.7 \pm 0.6$ & 4096 & $24.0 \pm 2.6$ & $0.5-1$ \\
\hline E. coli & ATCC 25922 & n.a. ${ }^{5}$ & N.D. ${ }^{6}$ & $19.7 \pm 0.6$ & 0.016 \\
\hline P. aeruginosa & ATCC 27853 & n.a. & N.D. & $21.7 \pm 0.6$ & 0.5 \\
\hline C. albicans & ATCC 24433 & $9.0 \pm 1.0$ & 512 & $16.33 \pm 0.58$ & 4.0 \\
\hline
\end{tabular}

${ }^{1}$ Ciprofloxacin for Gram-positive species, gentamicin for Gram-negative ones; nystatin for C. albicans. ${ }^{2}$ IZD, inhibition zone diameter. Each value is an average of three independent experiments with standard errors indicated. ${ }^{3}$ MIC; minimum inhibitory concentration. ${ }^{4}$ MRSA, Methicillin-Resistant Staphylococcus aureus. ${ }^{5}$ n.a., no activity. ${ }^{6}$ N.D., not determined.

In view of the appreciable activity against $S$. aureus, an additional series of $S$. aureus clinical isolates from catheter-associated infections was selected to confirm the observation and to prove the extendibility of the antimicrobial activity of the essential oil beyond the reference strain ATCC 29213. Four isolates were selected based on their proven resistance towards oxacillin, the congener of methicillin [25]. Hence, the four isolates were MRSA (methicillin-resistant Staphylococcus aureus). The MICs of essential oil against the clinical isolates were substantially superimposable to the one obtained against the reference strain, differing on average by one dilution (MIC $\cong 1024 \mu \mathrm{g} / \mathrm{mL}$ ). 


\subsection{NadD Inhibition Analysis}

In our effort to explore natural compounds against nicotinate mononucleotide adenylyltransferase of the NadD family [26,27], an essential enzyme of NAD biosynthesis in most bacteria, we evaluated the in vitro inhibition of E. floribundus essential oil against NadD from S. aureus. A preliminary single point inhibition test at the concentration of $80 \mu \mathrm{g} / \mathrm{mL}$ indicated a $\sim 60 \%$ inhibition with no effect on the ubiquitous mammalian isoform NMNAT1 [28]. Motivated by these results and by an observed broad-spectrum antimicrobial activity based on the diffusion IZD and MIC methods (Table 3), we performed a dose-response inhibition using an oil concentration range of $5-160 \mu \mathrm{g} / \mathrm{mL}$. The $\mathrm{IC}_{50}$ value of the essential oil for $S a N a d D$ was $98 \pm 11 \mu \mathrm{g} / \mathrm{mL}$.

\subsection{Antioxidant Activity}

Despite the interest on the bioactivity of E. floribundus based on its uses in Cameroonian traditional medicine, we evaluated for the first time the antioxidant properties of the essential oil. Antioxidant activity is a complex process usually occurring through several mechanisms and its evaluation is often carried out by more than one test method [29]. In this study, three antioxidant assays, namely DPPH free radical scavenging activity, ABTS radical cation scavenging activity, and ferric reducing antioxidant power (FRAP) were applied to evaluate the antioxidant properties of $E$. floribundus essential oil. As reported in Table 4, the antioxidant activity determined by DPPH radical scavenging ability showed a value of $16.9 \pm 0.1 \mu \mathrm{mol}$.(Trolox equivalents, TE) $/ \mathrm{g}$, with an $\mathrm{IC}_{50}$ value about 250 times higher than that of the positive control Trolox. Higher antioxidant activity was detected in the ABTS radical cation scavenging activity assay, with an average TE value of $85.5 \pm 3.6 \mu \mathrm{mol} \cdot \mathrm{TE} / \mathrm{g}$, and an $\mathrm{IC}_{50}$ value about 46 times higher than that of Trolox. It is noteworthy that the essential oil appeared to act as a good reducing agent (FRAP activity, TEAC $=411.9 \pm 2.40 \mu \mathrm{mol} \cdot \mathrm{TE} / \mathrm{g}$ ).

Table 4. Antioxidant activity of Erigeron floribundus essential oil.

\begin{tabular}{cccccc}
\hline & \multicolumn{2}{c}{ DPPH } & \multicolumn{2}{c}{ ABTS } & FRAP \\
\cline { 2 - 6 } & $\begin{array}{c}\text { TEAC }^{\mathbf{1}} \\
\mu \mathbf{m o l} \cdot \mathbf{T E} / \mathbf{g}\end{array}$ & $\begin{array}{c}\text { IC }_{\mathbf{5 0}}{ }^{2} \\
\mu \mathbf{g} / \mathbf{m L}\end{array}$ & $\begin{array}{c}\text { TEAC }^{\mathbf{1}} \\
\mu \mathbf{m o l} \cdot \mathbf{T E} / \mathbf{g}\end{array}$ & $\begin{array}{c}\text { IC }_{\mathbf{5 0}}{ }^{2} \\
\mu \mathbf{g} / \mathbf{m L}\end{array}$ & $\begin{array}{c}\text { TEAC }^{\mathbf{1}} \\
\mu \mathbf{m o l} \cdot \mathbf{T E} / \mathbf{g}\end{array}$ \\
\hline $\begin{array}{c}\text { E. floribundus oil } \\
\text { Trolox }\end{array}$ & $16.9 \pm 0.1$ & $356.7 \pm 7.1$ & $85.5 \pm 3.6$ & $74.9 \pm 3.2$ & $411.9 \pm 2.40$ \\
& & $1.51 \pm 0.04$ & & $1.6 \pm 0.01$ &
\end{tabular}

${ }^{1}$ TEAC: Trolox equivalent (TE) antioxidant concentration. ${ }^{2} \mathrm{IC}_{50}$ : The concentration giving a reduction of $50 \%$. Each value is an average of three independent experiments with standard errors indicated.

\subsection{Inhibition of T. brucei Proliferation}

A test of the E. floribundus oil against T. brucei proliferation showed that it was active at a much lower concentration than the Balb/3T3 mouse fibroblasts used as a control (Table 5). When analyzing some of the components in the oil, we found that limonene had a six times higher activity against T. brucei than the oil itself $\left(\mathrm{IC}_{50}=5.6 \mu \mathrm{g} / \mathrm{mL}\right)$ indicating that this is the major antitrypanosomal agent in E. floribundus oil. A calculation based on that limonene represents $8.8 \%$ of the oil and gives six times higher inhibition than the oil itself, which indicates that about half of the antitrypanosomal activity in the extract comes from limonene.

Table 5. Inhibition of T. brucei and Balb/3T3 fibroblast proliferation.

\begin{tabular}{cccc}
\hline & T. brucei $\mathrm{IC}_{\mathbf{5 0}}{ }^{\mathbf{1}}(\mu \mathrm{g} / \mathbf{m L})$ & Balb/3T3 $_{\text {IC }_{\mathbf{5 0}}{ }^{\mathbf{1}}(\mu \mathrm{g} / \mathbf{m L})}$ & Selectivity Index (SI) \\
\hline E. floribundus oil & $33.5 \pm 2.7$ & $>200$ & $>5.97$ \\
Carophyllene oxide & $>200$ & N.D. & $>17.85$ \\
Limonene & $5.6 \pm 1.6$ & $>100$ & \\
\hline
\end{tabular}

${ }^{1}$ Each value is an average of three independent experiments with standard errors indicated. 


\section{Discussion}

Only a few papers dealing with the chemical composition of E. floribundus essential oil are available in literature. From a comparison of our data with those of Kuiate et al. [9], we notice significant differences mainly from a quantitative point of view. In that study, the sesquiterpene hydrocarbons $(39.9 \%-74.8 \%)$ were revealed as predominant over oxygenated compounds $(7.0 \%-13.8 \%)$. The major representatives of these groups were the same but they occurred in different amounts, i.e., (E)-caryophyllene $(8.5 \%-20.1 \%),(E)$ - $\beta$-farnesene $(14.6 \%-24.1 \%)$, caryophyllene oxide $(0.8 \%-5.4 \%)$ and spathulenol $(1.0 \%-4.1 \%)$. Similarly, therein the monoterpenes hydrocarbons constituted a small fraction $(5.2 \%-17.3 \%)$, with limonene as the most abundant compound $(2.5 \%-11.4 \%)$. In addition, the presence of polyacetylenic constituents such as $(E)$-2-lachnophyllum ester $(3.4 \%-26.8 \%)$ was reported. We assume that the above differences may depend on chemical polymorphism of the species and different periods of collection.

This work reports on the cytotoxic activity of E. floribundus essential oil. A compound or few compounds do not emerge from the composition of essential oil, which can be responsible for the cytotoxic activity on human tumor cell lines. Caryophyllene oxide provided evidence of potent cytotoxic activity against HepG2, AGS, HeLa, SNU-1, and SNU-16 cells, with $\mathrm{IC}_{50}$ values of 3.95, $12.6,13.55,16.79$, and $27.39 \mu \mathrm{M}$, respectively [30]. Spathulenol was reported weakly active on human epidermoid carcinoma (KB) and inactive on human breast cancer (BC) and human small cell lung cancer (NCIH187) cell lines [31]. In addition, (E)-caryophyllene showed weak activity on the cell lines tested, with $\mathrm{IC}_{50}$ values ranging from 43.27 to $67.14 \mu \mathrm{g} / \mathrm{mL}$ for MDA-MB 231 and A375, respectively [32]. Our previous study has demonstrated that limonene showed antiproliferative activity on the same cell lines as tested above with $\mathrm{IC}_{50}$ values ranging from 18.4 to $124.0 \mu \mathrm{g} / \mathrm{mL}$, respectively [33]. Limonene also induces apoptosis in LS174T colon cancer cells and in a lymphoma cell line $\left(35 \mu \mathrm{g} / \mathrm{mL}, \mathrm{IC}_{50}\right)$ [34,35]. Moreover, it shows antitumor activity on lung adenocarcinoma A549 $\left(0.098 \mu \mathrm{L} / \mathrm{mL}, \mathrm{IC}_{50}\right)$ and hepatocarcinoma HepG2 cells $\left(0.150 \mu \mathrm{L} / \mathrm{mL}, \mathrm{IC}_{50}\right)$ [36]. To our knowledge, data reporting the cytotoxic activity of $(E)$ - $\beta$-farnesene are missing. However, the concentrations of caryophyllene oxide $(12.4 \%)$, spathulenol $(12.2 \%)$, limonene $(8.8 \%),(E)-\beta$-farnesene $(5.5 \%)$ and (E)-caryophyllene $(4.2 \%)$ cannot fully explain the cytotoxic activity of E. floribundus essential oil, which means that some other minor compounds contributed to the activity of the essential oil

The antimicrobial activity investigation revealed that the essential oil is mainly active against the Gram-positive bacteria. A special emphasis might be put on the results obtained with S. aureus. Both the reference strain and the methicillin-resistant clinical isolates from invasive infections were susceptible to the essential oil. Given the importance of $S$. aureus in human medical microbiology and food microbiology, the result is an important outcome. To our knowledge, this is the first study reporting on the antibacterial activity of the essential oil from E. floribundus. On the contrary, one single previous study investigated its antifungal activity [9]. Kuiate and coll. obtained a MIC equal to about $2 \mathrm{mg} / \mathrm{mL}$ against $C$. albicans, while in the present investigation the essential oil was inhibiting the yeast growth at $0.512 \mathrm{mg} / \mathrm{mL}$. Considering the differences in composition outlined above, it can be possible to speculate on the putative constituents contributing to the anti-Candida activity. Candidates might be spathulenol and caryophyllene oxide. The hypothesis on the first is not sustained by the literature where spathulenol is described solely as possessing anti-inflammatory properties. Caryophyllene oxide was instead already investigated for its antifungal properties and is approved by the FDA as a food and cosmetic preservative [37].

On the bacterial side, a hypothesis may be done with hexadecanoic acid: its concentration in the oil (2.5\%) could be compatible with its reported anti-staphylococcal activity [38].

Of note, the in vitro inhibition of NadD focusing on isolating individual components of the above oil mixtures that retain both such activities.

From radical scavenging activity assays (i.e., DPPH and ABTS, Table 4), we found that the E. floribundus essential oil displayed a weak activity. The chemical profile of the oil, with spathulenol $(12.2 \%)$, caryophyllene oxide $(12.4 \%)$ and limonene $(8.8 \%)$ as the major components, may partially 
justify the low inhibition on these radicals [39-41]. On the other hand, the high value of reducing power indicated that the essential oil components are able to act as electron donors and reduce the oxidized intermediate of lipid peroxidation so that they can act as primary and secondary antioxidants. Further studies are required to confirm the potential of this oil as reducing agent.

To the best of our knowledge, this is the first report on trypanocidal activity of the essential oil of E. floribundus, which further confirms the medical value of the plant. With an $\mathrm{IC}_{50}$ value of $5.6 \mathrm{\mu g} / \mathrm{mL}$ the lipophilic hydrocarbon limonene showed a quite remarkable trypanocidal activity against T. brucei. Additionally, limonene did not show significant toxicity in Balb/3T3 mouse fibroblasts $\left(\mathrm{IC}_{50}>100 \mu \mathrm{g} / \mathrm{mL}\right.$ ) and exhibited a favourable selectivity index (SI > 17.85). Its trypanocidal activity could be explained by the high degree of unsaturation (two double bonds) in its chemical structure. In addition, its exocyclic methylene group can easily react with $\mathrm{SH}$ groups in proteins (e.g., trypanothione synthase), thus enhancing its bioactivity by exposing the parasite to oxidative damage [42]. However, further investigations are required in order to clarify the mechanism of action of essential oil and limonene itself and to evaluate their therapeutic values for trypanosomiasis infections.

\section{Materials and Methods}

\subsection{Plant Materials}

Aerial parts of E. floribundus were harvested in Dschang, West Province of Cameroon (1450 m a.s.l.) in February 2013. The plant was identified at the Cameroon National Herbarium (Yaoundé), where a voucher specimen was deposited (5619SRF/Cam). Plant material was dried at room temperature in the shade for one week before undergoing total extraction.

\subsection{Hydrodistillation}

The dry aerial parts ( $500 \mathrm{~g}$ ) were reduced into small pieces, then subjected to hydrodistillation in a Clevenger-type apparatus for $4 \mathrm{~h}$ using $6 \mathrm{~L}$ of deionized water. The essential oil yield $(0.2 \%, n=3)$ was estimated on a dry-weight basis $(w / w)$. Once obtained, the oil was dried $\left(\mathrm{Na}_{2} \mathrm{SO}_{4}\right)$, transferred into an amber glass flask, and kept at $-20^{\circ} \mathrm{C}$ before chemical analysis and biological experiments.

\subsection{Chemicals}

For identification of volatiles the following analytical standards were purchased from Sigma-Aldrich (Milan, Italy): $\alpha$-pinene, $\beta$-pinene, $p$-cymene, limonene, $\gamma$-terpinene, linalool, trans-pinocarveol, terpinen-4-ol, $\alpha$-terpineol, myrtenol, nerol, carvone, geraniol, geranial, eugenol, $(E)$-caryophyllene, $\alpha$-humulene, $(E)$ - $\beta$-farnesene, $(E)$ - $\beta$-ionone, $(E)$-nerolidol, caryophyllene oxide, $n$-pentacosane, $n$-heptacosane; (E)-Phytol was previously isolated from Onosma echioides [43]. For retention-index (RI) determination, a mixture of hydrocarbons, ranging from octane $\left(\mathrm{C}_{8}\right)$ to triacontane $\left(\mathrm{C}_{30}\right)$ (Supelco, Bellefonte, PA, USA) was used and run under the experimental conditions reported below. All compounds were of analytical standard grade. Analytical-grade hexane solvent was purchased from Carlo Erba (Milan, Italy); it was successively distilled through a Vigreux column before use.

\subsection{Chemical Analysis of Essential Oil}

GC-MS Analysis was performed on an Agilent 6890N gas chromatograph (Santa Clara, CA, USA) coupled to a $5973 \mathrm{~N}$ mass spectrometer using two different capillary columns: a HP-5 MS column ( $5 \%$ phenylmethylpolysiloxane, $30 \mathrm{~m}, 0.25 \mathrm{~mm}$ i.d., $0.1-\mathrm{mm}$ film thickness; J \& W Scientific (Folsom, CA, USA), and a DB-WAX column (polyethylene glycol; $30 \mathrm{~m}, 0.25 \mathrm{~mm}$ i.d., 0.25-mm film thickness; $\mathrm{J} \& \mathrm{~W}$ Scientific,). The oven temperature program was the following: $5 \mathrm{~min}$ at $60{ }^{\circ} \mathrm{C}$, subsequently $4{ }^{\circ} \mathrm{C} / \mathrm{min}$ up to $220^{\circ} \mathrm{C}$, then $11^{\circ} \mathrm{C} / \mathrm{min}$ up to $280^{\circ} \mathrm{C}$, held for $15 \mathrm{~min}$, for a total run of $65 \mathrm{~min}$. Injector and detector temperatures were $280^{\circ} \mathrm{C}$. He was used as the carrier gas, at a flow rate of $1 \mathrm{~mL} / \mathrm{min}$. Split ratio, 1:50; acquisition mass range, $m / z$ 29-400. All mass spectra were acquired in 
electron-impact (EI) mode with an ionization voltage of $70 \mathrm{eV}$. Oil samples were diluted to 1:100 in $n$-hexane, and the volume injected was $2 \mu \mathrm{L}$. Whenever possible, the essential oil constituents were identified by co-injection with authentic standards. Otherwise, the peak assignment was carried out according to the recommendations of the International Organization of the Flavour Industry (http:/ / www.iofi.org/), i.e., by the interactive combination of chromatographic linear retention indices that were consistent with those reported in the literature [22-24] for apolar and polar stationary phases, and MS data consisting in computer matching with the WILEY275, NIST 08, ADAMS, FFNSC2 and home-made (based on the analysis of reference oils and commercially available standards) libraries. Quantification of essential oil components was achieved by peak-area internal normalisation without using correction factors.

\subsection{Antimicrobial Activity}

The essential oil of E. floribundus was tested against a panel of reference bacterial and yeast species including Staphylococcus aureus ATCC 25923, Escherichia coli ATCC 25922, Pseudomonas aeruginosa ATCC 27853, Enterococcus faecalis ATCC 29212, Candida albicans ATCC 24433. Extension of the investigation on S. aureus was accomplished using four additional S. aureus clinical isolates (Table 3) that were resistant to methicillin and maintained in the collection of the Microbiology Unit of the School of Pharmacy at the University of Camerino [25]. Bacterial strains were cultured overnight at $37^{\circ} \mathrm{C}$ in blood agar plates. C. albicans was grown in Sabouraud Dextrose Agar. Tests by the paper disc diffusion method were performed following the Clinical and Laboratory Standards Institute (CLSI) guidelines [44]. Briefly, a suspension of the tested microorganism $\left(1-2 \times 10^{8}\right.$ cells per $\mathrm{mL}$ in saline-10 per $\mathrm{mL}$ for Candida) was spread on the solid media plates using a sterile cotton swab. Sterile paper discs (6 mm in diameter) were placed on the surface of inoculated plates and spotted with $10 \mu \mathrm{L}$ of either the essential oil or $1 \mathrm{mg}$ of extract dissolved in DMSO. The plates were incubated $24 \mathrm{~h}$ at $35 \pm 1{ }^{\circ} \mathrm{C}$ ( $48 \mathrm{~h}$ for $\mathrm{C}$. albicans). The diameters of zone inhibition (including the $6 \mathrm{~mm}$ disc) were measured with a gauge. A reading of more than $6 \mathrm{~mm}$ indicated growth inhibition. No zone inhibition was observed using DMSO alone. Ciprofloxacin ( $5 \mu \mathrm{g}$ disc) and Nystatin (100 Units disc) were used as reference antimicrobials against bacteria and fungi, respectively. Each test was repeated at least twice. Antibiotic susceptibility testing by the microdilution method was performed following the international guidelines [44]. Briefly, two-fold serial dilutions of each mixture in Cation Adjusted Mueller Hinton Broth for bacteria and Roswell Park Memorial Institute (RPMI) 1640 for Candida were set in 96-well plates starting from $2048 \mathrm{mg} / \mathrm{L}$. An equal volume of the microbial inoculum $\left(10^{6} \mathrm{cfu} / \mathrm{mL}\right)$, obtained by direct colony suspension of an overnight culture, was added to each well of the microtiter plate containing $0.1 \mathrm{~mL}$ of the serially diluted test oil/extract. After incubation for $18-24 \mathrm{~h}$ at $35^{\circ} \mathrm{C}$, in normal atmosphere, Minimum Inhibitory Concentrations (MICs) were defined as the lowest concentration of compound able to inhibit the growth of the microorganisms. All tests were done in triplicate.

\subsection{Antioxidant Activity}

The antioxidant activity of E. floribundus essential oil was measured by using different radical generating systems (DPPH, ABTS and FRAP assay) to assess the free radical scavenging and reducing properties of the oil [45]. All the experiments were conducted in a 96-well microplate assay according to the method of Srinivasan et al. [46], for DPPH assay and following previously-described protocols by Re et al. [47], for measuring the total radical scavenging capacity on ABTS radical. The ferric reducing antioxidant power (FRAP assay) was carried out according to the procedure described by Müller et al. [48], by monitoring the reduction of $\mathrm{Fe}^{3+}$-tripyridyl triazine (TPTZ) to blue-coloured $\mathrm{Fe}^{2+}$-TPTZ. The ability of E. floribundus essential oil to scavenge the different radicals in all three assays was compared to Trolox used as standard. Results as tocopherol-equivalent antioxidant capacity (TEAC) were expressed in $\mu \mathrm{M}$ Trolox equivalents (TE)/g of essential oil. 


\subsection{Cytotoxic Activity on Tumor Cells}

A375 (human malignant melanoma cells) and MDA-MB 231 cells (human breast adenocarcinoma cells) were cultured in Dulbecco's Modified Eagle's Medium (DMEM) with 2 mM L-glutamine, $100 \mathrm{IU} / \mathrm{mL}$ penicillin, $100 \mu \mathrm{g} / \mathrm{mL}$ streptomycin, and supplemented with $10 \%$ heat-inactivated fetal bovine serum (HI-FBS). HCT116 cells (human colon carcinoma cells), were cultured in RPMI1640 medium with $2 \mathrm{mM}$ L-glutamine, $100 \mathrm{IU} / \mathrm{mL}$ penicillin, $100 \mu \mathrm{g} / \mathrm{mL}$ streptomycin, and supplemented with $10 \%$ HI-FBS. Cells were cultured in a humidified atmosphere at $37{ }^{\circ} \mathrm{C}$ in presence of $5 \%$ $\mathrm{CO}_{2}$. The MTT assay was used as a relative measure of cell viability. Cell-viability assays were carried out as described [49]. Briefly, cells were seeded at the density of $2 \times 10^{4}$ cells $/ \mathrm{mL}$. After $24 \mathrm{~h}$, samples were exposed to different concentrations of essential oil $(0.78-200 \mu \mathrm{g} / \mathrm{mL})$. Cells were incubated for $72 \mathrm{~h}$ in a humidified atmosphere of $5 \% \mathrm{CO}_{2}$ at $37{ }^{\circ} \mathrm{C}$. Cisplatin was used as the positive control $(0.05-20 \mu \mathrm{g} / \mathrm{mL})$. At the end of incubation, each well received $10 \mu \mathrm{L}$ of 3-(4,5-dimethyl-2-thiazolyl)-2,5-diphenyl-2H-tetrazoliumbromide (MTT) (5 mg/mL in phosphate-buffered saline, PBS) and the plates were incubated for $4 \mathrm{~h}$ at $37^{\circ} \mathrm{C}$. The extent of MTT reduction was measured spectrophotometrically at $540 \mathrm{~nm}$ using a Titertek Multiscan microElisa (Labsystems, Helsinki, Finland. Experiments were conducted in triplicate. Cytotoxicity is expressed as the concentration of compound inhibiting cell growth by $50 \%\left(\mathrm{IC}_{50}\right)$. The $\mathrm{IC}_{50}$ values were determined with the GraphPad Prism 4 computer program (GraphPad Software, San Diego, CA, USA).

\subsection{Enzyme Inhibition Assay}

Recombinant $S$. aureus NadD, available in our laboratory, was used as a representative bacterial target of the NadD enzyme family. Previous reports, indeed, have proven that this target enzyme is highly conserved in bacteria [17] and small molecule inhibitors may be simultaneously active on NadDs from distant species such as S. aureus and M. tuberculosis [50]. Murine NMNAT1 was chosen as the functionally equivalent mammalian enzyme [51].

The enzyme inhibition assay setup for the bacterial enzyme and the mammalian counter target is described in detail in Vitali et al. [27]. Briefly, enzyme rates and inhibition were measured by an established endpoint assay based on the detection at $620 \mathrm{~nm}$ of the phosphate byproduct formed [17]. A continuous assay based on detection at $340 \mathrm{~nm}$ of the reduced form of nicotinamide adenin dinucleotide (NADH) formed was used as an alternate assay [52].

\subsection{T. brucei and Mammalian Cell Culture}

T. brucei BSFs (TC221) were cultured at $37^{\circ} \mathrm{C}$ with $5 \% \mathrm{CO}_{2}$ in HMI-9 medium supplemented with $10 \%(v / v)$ heat-inactivated fetal bovine serum (Thermo Fisher Scientific [Gibco], Waltham, MA, USA). Mouse BALB/3T3 fibroblast (ATCC no CCL-163) were cultivated at $37{ }^{\circ} \mathrm{C}$ and $5 \% \mathrm{CO}_{2}$ in Dulbecco's modified Eagle's medium (Sigma-Aldrich), supplemented with 10\% $(v / v)$ heat-inactivated fetal bovine serum, glutamine $(0.584 \mathrm{~g} / \mathrm{L})$ and $10 \mathrm{~mL} / \mathrm{L} 100 \times$ penicillin-streptomycin (Thermo Fisher Scientific [Gibco]) [53].

\subsection{Growth Inhibition Assay on T. brucei and Balb/3T3 Cells}

The essential oil was dissolved in dimethyl sulfoxide (DMSO). It was serially diluted with growth medium to concentrations ranging from $2 \times 10^{-5}$ to $200 \mu \mathrm{g} / \mathrm{mL}$ in 96 -well microtiter plates (100 $\mathrm{L}$ /well). Subsequently, $100 \mu \mathrm{L}$ of $\mathrm{T}$. brucei or mammalian cell culture was added to each well (20,000 cells/well). After $48 \mathrm{~h}$ incubation, the plates were treated for $24 \mathrm{~h}$ with $20 \mu \mathrm{L}$ of resazurine (Sigma-Aldrich). They were subsequently quantified by fluorescence (540 nm excitation and $590 \mathrm{~nm}$ emission) using an Infinite M200 microplate reader (Tecan Group Ltd., Männedorf, Switzerland). The $\mathrm{IC}_{50}$ values were calculated by fitting the data to a log inhibitor vs. response curve (variable slope, four parameters) using the GraphPad Prism version 5.04 software. 


\section{Conclusions}

The present work provides new insights into the phytochemical and biological properties of E. floribundus. The essential oil of this plant revealed a good potential as bacterial NadD inhibitor, thus being a promising candidate for antibiotic formulations. The exhibited trypanocidal activity, on one hand, confirmed partially the traditional use in the treatment of protozoal diseases, and on the other hand, makes it a potential candidate for standardized herbal medicines against trypanosomiasis that are highly requested in developing countries with poor medical infrastructure and difficult access to conventional medical treatments.

Acknowledgments: The authors would like to thank the University of Camerino (FAR 2014/15, Fondo di Ateneo per la Ricerca, FPI000044) for financial support. Anders Hofer also thanks the Swedish Research Council (2012-1932) and the Kempe Foundation.

Author Contributions: The contributions of the respective authors are as follows: P.C. Biapa Nya collected the plant material; F. Maggi performed hydrodistillation and supervised the GC analyses, as well as interpreted the data to prepare the manuscript; R. Petrelli and L. Cappellacci conceived the research and edited and revised the manuscript; D. Petrelli and L.A. Vitali performed the antimicrobial experiments; L. Sorci and G. Orsomando carried out experiments on enzymes; F. Ranjbarian and A. Hofer conducted the tests for antitrypanosomal activity; G. Lupidi executed the antioxidant assays; L. Quassinti and M. Bramucci evaluated the cytotoxic activity on tumor cells. All authors read and approved the manuscript.

Conflicts of Interest: The authors declare no conflict of interest.

\section{References}

1. Asongalem, E.A.; Foyet, H.S.; Ngogang, J.; Folefoc, G.N.; Dimo, T.; Kamtchouing, P. Analgesic and antinflammatory activities of Erigeron floribundus. J. Ethnopharmacol. 2004, 91, 301-308. [CrossRef] [PubMed]

2. Yapo, F.A.; Yapi, F.H.; Ahiboh, H.; Hauhouot-Attounbre, M.L.; Guédé, N.Z.; Djaman, J.A.; Monnet, D. Immunomodulatory effect of the aqueous extract of Erigeron floribundus (Kunth) Sch. Beep. (Asteraceae) leaf in rabbits. Trop. J. Pharm. Res. 2011, 10, 187-193. [CrossRef]

3. Atindenou, K.K.; Koné, M.; Terreaux, C.; Traore, D.; Hostettemann, K.; Dosso, M. Evaluation of the antimicrobial activity of medicinal plants from the Ivory Coast. Phytother. Res. 2002, 16, 497-502. [CrossRef] [PubMed]

4. Etchikié, C.A.; Sassa, A.M.; Abba, A.; Nyonbourg, E. Evaluation in vitro de l'activité antibactérienne de cinq plantes de la pharmacopée traditionnelle de l'Adamaoua (Cameroun). Cameroon J. Exp. Biol. 2011, 7, $22-27$.

5. Telefo, P.B.; Lienou, L.L.; Yemele, M.D.; Lemfack, M.C.; Mouokeu, C.; Goka, C.S.; Tagne, S.R.; Moundipa, F.P. Ethnopharmacological survey of plants used for the treatment of female infertility in Baham, Cameroon. J. Ethnopharmacol. 2011, 136, 178-187. [CrossRef] [PubMed]

6. Koné, M.; Atindehou Kamanzi, K.; Traoré, D. Plantes et médecine traditionnelle dans la région de Ferkessédougou (Côte d'Ivoire). Annales de Botanique de l'Afrique de l'Ouest 2002, 2, 13-23.

7. Tra Bi, F.H.; Koné, M.W.; Kouamé, N.F. Antifungal activity of Erigeron floribundus (Asteraceae) from Côte d'Ivoire, West Africa. Trop. J. Pharm. Res. 2008, 7, 975-979. [CrossRef]

8. Ménan, H.; Banzouzi, J.T.; Hocquette, A.; Pélissier, Y.; Blache, Y.; Koné, M.; Mallié, M.; Assi, L.A.; Valentin, A. Antiplasmodial activity and cytotoxicity of plants used in West African traditional medicine for the treatment of malaria. J. Ethnopharmacol. 2006, 105, 131-136.

9. Kuiate, J.R.; Tsona, A.A.; Foko, J.; Bessiere, J.M.; Menut, C.; Amvam Zollo, P.H. Chemical composition and in vitro antifungal properties of essential oils from leaves and flowers of Erigeron floribundus (H.B. et K.) Sch. Bip. from Cameroon. J. Essent. Oil Res. 2005, 17, 261-264. [CrossRef]

10. Solórzano-Santos, F.; Miranda-Novales, M.G. Essential oils from aromatic herbs as antimicrobial agents. Curr. Opin. Biotechnol. 2012, 23, 136-141. [CrossRef] [PubMed]

11. Nibret, E.; Wink, M. Trypanocidal and antileukaemic effects of the essential oils of Hagenia abyssinica, Leonotis ocymifolia, Moringa stenopetala, and their main individual constituents. Phytomedicine 2010, 17, 911-920. [CrossRef] [PubMed]

12. Pavela, R. Essential oils for the development of eco-friendly mosquito larvicides: A review. Ind. Crops Prod. 2015, 76, 174-187. [CrossRef] 
13. Bilia, A.R.; Guccione, C.; Isacchi, B.; Righeschi, C.; Firenzuoli, F.; Bergonzi, M.C. Essential oils loaded in nanosystems: A developing strategy for a successful therapeutic approach. Evid. Based Complement. Altern. Med. 2014, 2014, 651593. [CrossRef] [PubMed]

14. Sorci, L.; Cimadamore, F.; Scotti, S.; Petrelli, R.; Cappellacci, L.; Franchetti, P.; Orsomando, G.; Magni, G. Initial-rate kinetics of human NMNadenylyltransferases: Substrate and metal ion specificity, inhibition by products and multisubstrate analogues, and isozyme contributions to NAD ${ }^{+}$biosynthesis. Biochemistry 2007, 46, 4912-4922. [CrossRef] [PubMed]

15. Sorci, L.; Kurnasov, O.; Rodionov, D.A.; Osterman, A.L. Genomics and Enzymology of NAD Biosynthesis. Comprehensive Natural Products II Chemistry and Biology; Elsevier: Oxford, UK, 2010; Volume 7, pp. $213-257$.

16. Petrelli, R.; Felczak, K.; Cappellacci, L. NMN/NaMN adenylyltransferase (NMNAT) and NAD kinase (NADK) inhibitors: Chemistry and potential therapeutic applications. Curr. Med. Chem. 2011, 18, 1973-1992. [CrossRef] [PubMed]

17. Sorci, L.; Pan, Y.; Eyobo, Y.; Rodionova, I.; Huang, N.; Kurnasov, O.; Zhong, S.; Mackerell, A.D., Jr.; Zhang, H.; Osterman, A.L. Targeting NAD biosynthesis in bacterial pathogens: Structure-based development of inhibitors of nicotinate mononucleotide adenylyltransferase NadD. Chem. Biol. 2009, 16, 849-861. [CrossRef] [PubMed]

18. Huang, N.; Kolhatkar, R.; Eyobo, Y.; Sorci, L.; Rodionova, I.; Osterman, A.L.; Mackerell, A.D.; Zhang, H. Complexes of bacterial nicotinate mononucleotide adenylyltransferase with inhibitors: implication for structure-based drug design and improvement. J. Med. Chem. 2010, 53, 5229-5239. [CrossRef] [PubMed]

19. Sorci, L.; Blaby, I.K.; Rodionova, I.A.; De Ingeniis, J.; Tkachenko, S.; de Crécy-Lagard, V.; Osterman, A.L. Quinolinate salvage and insights for targeting NAD biosynthesis in group A streptococci. J. Bacteriol. 2013, 195, 726-732. [CrossRef] [PubMed]

20. Rodionova, I.A.; Schuster, B.M.; Guinn, K.M.; Sorci, L.; Scott, D.A.; Li, X.; Kheterpal, L.; Shoen, C.; Cynamon, M.; Locher, C.; et al. Metabolic and bactericidal effects of targeted suppression of NadD and NadE enzymes in mycobacteria. mBio 2014, 5, 245-256. [CrossRef] [PubMed]

21. Scotti, L.; Mendonça, F.J.; da Silva, M.S.; Scotti, M.T. Enzymatic Targets in Trypanosoma brucei. Curr. Protein Pept. Sci. 2016, 17, 243-259. [CrossRef] [PubMed]

22. Adams, R.P. Identification of Essential Oil Components by Gas Chromatography/Mass Spectroscopy; Allured Publishing Co.: Carol Stream, IL, USA, 2007.

23. NIST 08. National Institute of Standards and Technology. Mass spectral library (NIST/EPA/NIH); National Institute of Standards and Technology: Gaithersburg MD, USA, 2008.

24. FFNSC 2. Flavors and Fragrances of Natural and Synthetic Compounds. Mass spectral database; Shimadzu Corps: Kyoto, Japan, 2012.

25. Petrelli, D.; Repetto, A.; D'Ercole, S.; Rombini, S.; Ripa, S.; Prenna, M.; Vitali, L.A. Analysis of meticillin-susceptible and meticillin-resistant biofilm-forming Staphylococcus aureus from catheter infections isolated in a large Italian hospital. J. Med. Microbiol. 2008, 57, 364-372. [CrossRef] [PubMed]

26. Orsomando, G.; Agostinelli, S.; Bramucci, M.; Cappellacci, L.; Damiano, S.; Lupidi, G.; Maggi, F.; Ngahang Kamte, S.L.; Biapa Nya, P.C.; et al. Mexican sunflower (Tithonia diversifolia, Asteraceae) volatile oil as a selective inhibitor of Staphylococcus aureus nicotinate mononucleotide adenylyltransferase (NadD). Ind. Crops Prod. 2016, 85, 181-189. [CrossRef]

27. Vitali, L.A.; Beghelli, D.; Biapa Nya, P.C.; Bistoni, O.; Cappellacci, L.; Damiano, S.; Lupidi, G.; Maggi, F.; Orsomando, G.; Papa, F.; et al. Diverse biological effects of the essential oil from Iranian Trachyspermum ammi. Arabian J. Chem. 2015, 26. [CrossRef]

28. Mori, V.; Amici, A.; Mazzola, F.; Di Stefano, M.; Conforti, L.; Magni, G.; Ruggieri, S.; Raffaelli, N.; Orsomando, G. Metabolic profiling of alternative NAD biosynthetic routes in mouse tissues. PLoS ONE 2014, 9, e113939. [CrossRef] [PubMed]

29. Aruoma, O.I. Methodological considerations for characterizing potential antioxidant actions of bioactive components in plant foods. Mutat. Res. Fundam. Mol. Mech. Mutagen. 2003, 523-524, 9-20.

30. Jun, N.J.; Mosaddik, A.; Moon, J.Y.; Jang, K.C.; Lee, D.S.; Ahn, K.S.; Cho, S.K. Cytotoxic activity of beta-caryophyllene oxide isolated from Jeju guava (Psidium cattleianum Sabine) leaf. Rec. Nat. Prod. 2011, 5, 242-246. 
31. Prawat, U.; Chairerk, O.; Lenthas, R.; Salae, A.W.; Tuntiwachwuttikul, P. Two new cycloartane-type triterpenoids and one new flavanone from the leaves of Dasymaschalon dasymaschalum and their biological activity. Phytochem. Lett. 2013, 6, 286-290. [CrossRef]

32. Venditti, A.; Bianco, A.; Nicoletti, M.; Quassinti, L.; Bramucci, M.; Lupidi, G.; Vitali, L.A.; Petrelli, D.; Papa, F.; Vittori, S.; et al. Phytochemical analysis, biological evaluation and micromorphological study of Stachys alopecuros (L.) Benth. subsp. divulsa (Ten.) Grande endemic to central Apennines, Italy. Fitoterapia 2013, 90, 94-103. [CrossRef] [PubMed]

33. Fogang, H.P.D.; Tapondjou, L.A.; Womeni, H.M.; Quassinti, L.; Bramucci, M.; Vitali, L.A.; Petrelli, D.; Lupidi, G.; Maggi, F.; Papa, F.; et al. Characterization and biological activity of essential oils from fruits of Zanthoxylum xanthoxyloides Lam. and Z. leprieurii Guill. \& Perr., two culinary plants from Cameroon. Flav. Fragr. J. 2012, 27, 171-179.

34. Jia, S.S.; Xi, G.P.; Zhang, M.; Chen, Y.B.; Lei, B.; Dong, X.S.; Yang, Y.M. Induction of apoptosis by D-limonene is mediated by inactivation of Akt in LS174T human colon cancer cells. Oncol. Rep. 2013, 29, 349-354. [PubMed]

35. Manuele, M.G.; Ferraro, G.; Anesini, C. Effect of Tilia x viridis flower extract on the proliferation of a lymphoma cell line and on normal murine lymphocytes: Contribution of monoterpenes, especially limonene. Phytother. Res. 2008, 22, 1520-1526. [CrossRef] [PubMed]

36. Manassero, C.A.; Girotti, J.R.; Mijailovsky, S.; García de Bravo, M.; Polo, M. In vitro comparative analysis of antiproliferative activity of essential oil from mandarin peel and its principal component limonene. Nat. Prod. Res. 2013, 2, 1475-1478. [CrossRef] [PubMed]

37. Yang, D.; Michel, L.; Chaumont, J.P.; Millet-Clerc, J. Use of caryophyllene oxide as an antifungal agent in an in vitro experimental model of onychomycosis. Mycopathologia 2000, 148, 79-82. [CrossRef]

38. Clarke, S.R.; Mohamed, R.; Bian, L.; Routh, A.F.; Kokai-Kun, J.F.; Mond, J.J.; Tarkowski, A.; Foster, S.J. The Staphylococcus aureus surface protein IsdA mediates resistance to innate defenses of human skin. Cell Host Microbe 2007, 1, 199-212. [CrossRef] [PubMed]

39. De Souza Araújo, C.; de Oliveira, A.P.; Lima, R.N.; Alves, P.R.; Diniz, T.C.; da Silva Almeida, J.R.G. Chemical constituents and antioxidant activity of the essential oil from leaves of Annona vepretorum Mart. (Annonaceae). Pharmacogn. Mag. 2015, 11, 615-618.

40. Sonboli, A.; Esmaeili, M.A.; Gholipour, A.; Kanani, M.R. Composition, cytotoxicity and antioxidant activity of the essential oil of Dracocephalum surmandinum from Iran. Nat. Prod. Comm. 2010, 5, 341-344.

41. Gürsoy, N.; Tepe, B.; Akpulat, H.A. Chemical Composition and Antioxidant Activity of the Essential Oils of Salvia palaestina (Bentham) and S. ceratophylla (L.). Rec. Nat. Prod. 2012, 6, 278-287.

42. Wink, M. Evolutionary advantage and molecular modes of action of multi-component mixtures used in phytomedicine. Curr. Drug Metab. 2008, 10, 996-1009. [CrossRef]

43. Maggi, F.; Tirillini, B.; Vittori, S.; Sagratini, G.; Papa, F. Analysis of the Volatile Components of Onosma echioides (L.) L. var. columnae Lacaita Growing in Central Italy. J. Essent. Oil Res. 2009, 21, 441-447. [CrossRef]

44. CLSI (Clinical and Laboratory Standards Institute). Performance Standards for Antimicrobial Disk Susceptibility Tests, 10th ed.; Approved standard M02-A10; CLSI: Wayne, MI, USA, 2009.

45. Maggi, F.; Randriana, R.F.; Rasoanaivo, P.; Nicoletti, M.; Quassinti, L.; Bramucci, M.; Lupidi, G.; Petrelli, D.; Vitali, L.A.; Papa, F.; et al. Chemical composition and in vitro biological activities of the essential oil of Vepris macrophylla (Baker) I. Verd. Endemic to Madagascar. Chem. Biodivers. 2013, 10, 356-366. [CrossRef] [PubMed]

46. Srinivasan, R.; Chandrasekar, M.J.N.; Nanjan, M.J.; Suresh, B. Antioxidant activity of Caesalpinia digyna root. J. Ethnopharmacol. 2007, 113, 284-291. [CrossRef] [PubMed]

47. Re, R.; Pellegrini, N.; Proteggente, A.; Pannala, A.; Yang, M.; Rice-Evans, C. Antioxidant activity applying an improved ABTS radical cation decolorization assay. Free Rad. Biol. Med. 1999, 26, 1231-1237. [CrossRef]

48. Müller, L.; Frohlich, K.; Bohm, V. Comparative antioxidant activities of carotenoids measured by ferric reducing antioxidant power (FRAP), ABTS bleaching assay ( $\alpha$ TEAC), DPPH assay and peroxyl radical scavenging assay. Food Chem. 2011, 129, 139-148. [CrossRef]

49. Quassinti, L.; Lupidi, G.; Maggi, F.; Papa, F.; Vittori, S.; Bianco, A.; Bramucci, M. Antioxidant and antiproliferative activity of Hypericum hircinum L. subsp. majus (Aiton) N. Robson essential oil. Nat. Prod. Res. 2013, 27, 862-868. [CrossRef] [PubMed] 
50. Rodionova, I.A.; Zuccola, H.J.; Sorci, L.; Aleshin, A.E.; Kazanov, M.D.; Ma, C.T.; Sergienko, E.; Rubin, E.J.; Locher, C.P.; Osterman, A.L. Mycobacterial nicotinate mononucleotide adenylyltransferase: structure, mechanism, and implications for drug discovery. J. Biol. Chem. 2015, 290, 7693-7706. [CrossRef] [PubMed]

51. Orsomando, G.; Cialabrini, L.; Amici, A.; Mazzola, F.; Ruggieri, S.; Conforti, L.; Janeckova, L.; Coleman, M.P.; Magni, G. Simultaneous single-sample determination of NMNAT isozyme activities in mouse tissues. PLos ONE 2012, 7, e53271. [CrossRef] [PubMed]

52. Balducci, E.; Emanuelli, M.; Raffaelli, N.; Ruggieri, S.; Amici, A.; Magni, G.; Orsomando, G.; Polzonetti, V.; Natalini, P. Assay methods for nicotinamide mononucleotide adenylyltransferase of wide applicability. Anal. Biochem. 1995, 228, 64-68. [CrossRef] [PubMed]

53. Hirumi, H.; Hirumi, K. Continuous cultivation of Trypanosoma brucei blood stream forms in a medium containing a low concentration of serum protein without feeder cell layers. J. Parasitol. 1989, 75, 985-989. [CrossRef] [PubMed]

Sample Availability: Samples of the essential oil from Erigeron floribundus are available from the authors.

(C) 2016 by the authors; licensee MDPI, Basel, Switzerland. This article is an open access article distributed under the terms and conditions of the Creative Commons Attribution (CC-BY) license (http://creativecommons.org/licenses/by/4.0/). 